\title{
The Effects of the Basic Conditions of Employment, Act no. 97 on Domestic Workers in South Africa
}

\author{
Mokoko Sebola \\ University of Limpopo, South Africa
}

Doi:10.5901/mjss.2014.v5n6p123

\begin{abstract}
The purpose of this paper is to argue that the adoption of government policies in South Africa to regulate the relationship between the employer and the employee by pleasing one party rather than both is responsible for more exploitation of labourers in the domestic sector, than before the policy was put into effect, therefore leading to a policy to achieve lesser benefits for intended beneficiaries. Domestic workers worldwide are believed to be abused and their rights infringed by their employers. Domestic work in South Africa is provided to low, middle and high income earners in the country depending on the nature of work done by the employee. This service is usually provided by families from poor background with little or no income generated in the household except the one received from the employer. Generally poor families are vulnerable to exploitation by their employees in the society. Previously the South African government did not have a clear policy regulating the wages and employment of people in this sector. This has led to the exploitation of employees in the sector through lower wages, long hourly services and various forms of labour abuse without employee benefits in all respects. The Basic Conditions of Employment Act of 1997 responded to this problem in this sector as well as other employee sectors in the country, however, varied responses were seen from the employment market in the sector leading to negative consequences of which intended beneficiaries have to settle for less without reasonable options available to them from the policy. This paper therefore raises the following important research questions: * What are the effects of the Basic Conditions of Employment Act of 1997 on South Africans employed in the domestic sector? * What are the policy benefits and de-benefits on employees in the domestic sector?

* What are the probable solutions of this policy on accommodating both the interest of the employer and the employees?
\end{abstract}

\section{Introduction}

The International Labour Organization (ILO) achieved a breakthrough in June 2011 when a legal framework was put in place to regulate the working conditions of the domestic workers (Sjoberg, 2011:5). The purpose of the framework was to ensure that this sector of the employment category receives similar rights and is accorded the same status and respect like any other employment category. South Africa has since 1994 being a signatory of many international conventions and has included the domestic workers under national labour law since 1993 and at the same time has adopted the Basic Conditions of Employment Act (1997) prior to the reaction by the United Nations, through its ILO in June 2011. The Department of Labour in South Africa has the Inspectorate division that deals with enforcement of the act by employees as well as sanctions for failing to comply. The regularization of this act on employers is vulnerable to flaws and a cause of unemployment and abuse for employees in that category if unconsciously attended to. This paper therefore argues that the enforcement of this act without proper cost-benefit analysis is a cause for rising unemployment and employee abuse in the domestic sector category in South Africa. This paper will therefore limit its relevance to the conceptualization of the Domestic work, the recognition of domestic workers in the international context, the significance of the Basic Conditions of Employment Act on South African Domestic workers, the effects of Basic Conditions of Employment on Employment of South African domestic workers.

\section{Conceptualising "Domestic Work"}

The concept Domestic worker refers to an individual employee in a private home performing duties such as cleaning, child care, driving, gardening, cooking, elderly and frail care (Curry, 2011:1; Sjoberg, 2011:1). While it is argued that there is no a real definition, but is suffices to conclude that domestic work is performed or carried out within the sphere of home, in the employers residence or in his or her premises (International Labour Organisation, 2006). Some research institutions such as Statistics South Africa's exclude the gardeners from the definition of domestic work (Hertz, 2005:6). In South Africa this kind of duties are performed by individuals from the poor family background. In some instances this kind of employees are members of either a minority ethnic, national or religious group in the country of employment (Babin, 
2013:1). This therefore implies that such individuals are vulnerable and have limited influence on matters affecting their work life. To a larger extent a major category of these employees are women with less formal education in which instance that renders them vulnerable to exploitation and sexual harassment (Curry, 2011:1-2). This therefore makes a need for skills development in this sector to be imperative. The practicability of this initiative may however be impossible and depend on the type of domestic work one is performing. In most instances domestic workers are fully engaged individuals who form part of the daily routines in the family of employment to the extent that missing a day at work makes it impossible for the employing family to cope. On the other hand an employer who can afford the usage of more than one domestic worker could be able to afford them leave days and study opportunities because they can substitute one another. Despite the existence of democracy in South Africa little seems to have been done about the improvement of the working conditions of the domestic sector (Dilata \& Ngoepe, 2010:1; Employment Conditions Commission, nd: 1). The practical realities in the sector seem to be contradictory in some aspects to the extent that not only are the employers not complying, but also the employees influencing the employers to fail to comply because of their desperate need for employment. In the agricultural sector which is highly dominated by employees for war torn and economically corrupted and bankrupted countries, it becomes difficult for employees to settle for a so called living wage. On the other hand employers in the domestic sector have no social class. There are compelling circumstances that forces individuals across the social class to employ others as domestics.

\section{Domestic Workers in International Context}

Generally it is argued that there are no international instruments for protection of domestic workers except international legal instrument meant to protect domestic workers in a manner that is direct or indirect (International Labour Organization, 2006:19). Domestic work is an international phenomenon as much as numerous issues associated with it (Du Toit, 2010). At international level the International Convention on decent work has accorded the domestic workers minimum working rights and protection. This type of work has in most of the time being unregulated worldwide because of its informal nature and therefore subjecting the employees in that sector to severe maltreatment and abuse. The International labour Organisation (2012:1) reported that 56,6 million men and women worldwide are employed as domestic workers. The inclusion of domestic workers under the umbrella of decent work was endorsed by the international community as a productive sector for men and woman in a freedom of freedom, equity, security and human dignity (Du Toit, 2010 and International Labour Organisation, 2012).

The recognition of domestic work is however considered differently from one country to the other. To this extent it means that while other countries may consider other rights such as human dignity and equality, but countries differ in regard to recognition of those rights. Countries such as Italy, Panama, Paraguay, Peru, Portugal, Spain, South Africa, Vietnam and Zimbabwe have laws that entitle their domestic workers to maternity and protection from termination (International Labour Organisation, 2006:34). On the other hand while human rights and equity are protected, the ILO is not prescriptive of wages which are the most significant aspects of domestic employment. It is therefore within the rights of individual countries to prescribe minimum wages that shows respect and dignity on domestic workers. While in developing countries the domestic worker legislation are mainly meant to protect the locals against the employer abuses (such legislation are quite about immigrants), in developed countries such as United States of America and the United Kingdom have most of this kind of legislation trying to protect immigrants domestic workers against abuse by the local employees (Freeman, Roberts, Tretjak \&Wiener, 2003:1-19). Laws in this regard may differ from one state to the other in the United States of America.

\section{Significance of the Basic Conditions of Employment Act, on Domestic Workers in South Africa}

The significance of this act lies in the fact that it ensures the domestic workers rights to human dignity and decent working conditions. Unlike before the act, where domestic workers rights were limited and can be fired without a notice, the act provides for domestic workers to have protected rights in the form of entitlements to maternity leaves and other forms of leaves, working hours and Unemployment Insurance Fund.

Also significant to this act is the change of attitudes of employment that was based on racial prediduce. Domestic work in the country was performed by blacks and employers being white, and therefore with some fairly black employees regarding it mostly as an act to protect them against ruthless white employees. It cannot be overlooked that postapartheid South Africa has created a new crop of black elite employers in the same category.

In South Africa, domestic work is regulated by a specific "Sectoral determination" under Basic Conditions of Employment Act which applies to all domestic workers and provides standards across a whole range of areas 
(International Labour Organisation, 2006). The sectoral determination includes and not limited to the following:

- Provision of minimum wage for domestic workers differing according to whether they are urban or non-urban areas.

- Clear guidelines as to what deductions could be made from the domestic workers salary.

- Right of all live in rooms that is "weather proof and generally kept in good conditions, with at least one window and a door, and access to toilet and bath or shower.

- Rights of all domestic workers to "written particulars" of their wages and duties.

- Time limit and minimum wages when they are on standby.

- Meal breaks every five hours.

- Four months maternity leave

\section{Employers and Employees in the South African Domestic Sector}

In South Africa the employment of domestic work is not easy to define and the least to implement it. It is often assumed that the employment of domestic workers is a sole monopoly of the middle class and the wealthy while that is not necessarily the correct assertion. In South Africa the employment of domestic workers is not an activity limited to a particular class of the society, but rather cut across classical status. Domestic work is a service based on the need of the employer irrespective of the status in which the low income earning domestic workers who are paid the so called minimum wages set by the government also needs to have a domestic worker in their households to take care of their activities while away. Stiell \& England (1997) argues that women are likely to hire domestic workers if they feel that they can't cope with domestic labour in their households. In this instance conformity by the low income domestic earner becomes practically impossible. One of the major defects of this legislation is that it uses a one size fit all approach in the sense that employees irrespective of their categories are capable of affording a living wage for their employees. This is not necessarily the case in most circumstances where domestic work is even a need for the lower class employees. This being an aspect that was overlooked in South Africa often results in negative effects that adverse negatively on employees in the domestic sector.

\section{The Effects of Basic Conditions of Employment Act, 97 on Domestic Workers}

There is no argument that the Act is not significant in protecting the rights and dignity of employees in this category. The protection of these rights and dignity should however not be viewed outside the perspective of the negative effects associated with the other de-benefits of the policy. Of significant there are effects such as reduced employment rate in the sector, strengthening formal organisations and "the beggars and no choosers options"

\subsection{Reduced employment in the sector}

The theory on minimum wages implies that effects are possible in which most of them could be adverse to the beneficiaries and companies at the same time (Bothma \& Campher 2003:190). Of significant in this discussion, is the decrease in employment. The Department of Labour (2001) using the World Bank model also established that between $6 \%$ of (rural domestic workers) and $5 \%$ (of urban) domestic workers could lose their jobs if the minimum wages were to be implemented through this act in the domestic sector. However, the estimates were discarded as the model was said to be unreliable and that such percentages could have been exaggerated because the model showed some flaws in its own calculations. The formalisation of the sector such as the requirements of contract and salary advises may be a major concern for employers in the sector. Burgher \& Fintel (2009:3) noted that South Africa has the highest rate of unemployment in the world and to this extent the minimum wages for the domestic workers is indeed a potential threat to the sector. Statistics indicated that in September 2000 there were about 1. 025 million employees in the domestic sector (Gobind, du Plessis \& Ukpere, 2012; Matjeke, Viljoen \& Blaauw, 2012). In 2003 the figure went down to 977000 employees in which it could be assumed that; that was the effect of the enactment of the minimum wage legislation in 2002. The figure did however improved to a million between the periods 2007 and 2010 (Statistics South Africa, 2009:15; Department of Labour, 2010). The improvement of this figure is what really matters as the improvement may be emanating from the abuse of the vulnerable employees who have no option but to accept what employers can provide. 


\subsection{Strengthening formal organisations}

It should be noted that the employment of domestic workers in South Africa is both needs based and an optional affair by employers. Most employers may employ a domestic worker for physical security other than need requirements or employ a nannie for both reasons of ensuring physical presence and cleaning of the households. Employers basically have options; and some of these options threaten the purpose of the minimum wage act to improve the employment conditions of the domestic workers. Those are options that include domestic worker employers sending their children to crèches and pre-schools for care or even installing security systems in their households for safety. The option is often regarded as a cheaper replacement costs. Studies conducted by Matjeke et al (2012) demonstrated that current youthful middle class residential areas such as Orchards in Pretoria attract more domestic workers in the category of child and elder care than township settlements such as Soshanguve in the same area. Therefore minimum wage legislation pose the risk reducing the need for domestic workers in most employers' households and in most cases strengthening the middle class employees who most of them will create formal businesses in the form of pre-schools and crèches. A study conducted by Bothma \& Campher (2003) in Langenhoven (A white suburb in Bloemfontein) revealed that the employers reactions about the minimum wage as proposed by the government was that they will either reduce the hourly rates of their employees or to terminate the contract of their domestic workers. All the two optional reactions have the potential to adverse negatively on domestic employees. The options are likely to give employers to look for other alternatives which can serve their interest better.

\subsection{The beggars and the chooser's options}

Literature on this subject reveals that prior to the implementation of the minimum wage act there has been a tremendous decrease of employees in the domestic sector and a tremendous decrease later (Statistics South Africa, 2009:15; Department of Labour, 2010;Gobind, du Plessis \& Ukpere, 2012; Matjeke, Viljoen \& Blaauw, 2012). There is however no literature that provide reasons for the increase that took place in the years 2007 and 2010 as reported by studies conducted by the Department of Labour and Statistics South Africa for the stated years. This article will argue that the decrease was due to employers terminating contracts because they could not cope with minimum wage and formalities created by the government with regard to employment of domestic workers. On the other hand realising that beggars are not choosers, the employees in the domestic sector settled for whatever employers can provide to them and hence the increase in the sector again from 2007 and other ensuing years. Blaauw \& Bothma (2010) have however argued that previous studies failed to establish a significant relationship between the minimum wage legislation and the decrease in domestic sector employment. Further causes could and not being limited to; employers employing immigrants than locals because they settle for less as they lack options( Pheko, 2012:3) and employers only employing part time domestic workers as a way of reducing own expenditure from hourly rates. South Africa has been identified to be a country with high rate of unemployment of low skilled workers (Altman, 2006) and in most cases women hold unskilled or semi-skilled jobs (African National Congress, 2013). In a developing country like South Africa where women empowerment is still being acted on and not benefiting the majority as expected; the country has little leverage on employers whom the domestic workers may perceive better as employers than empty promises of job creation from government. Du Toit (2010) has argued that thus far the effect of the regulation of the domestic services have produced two contradicting perspectives, namely; the other one depicting success while the other one depicted continued abuse of domestic workers by using their services under appalling conditions. From this analogy it is clear that the first perception which was derived from studies conducted on improvement of wages other than working conditions a success was therefore recorded because the wages improved while employment in the sector decreased. On the other hand the second perception is mainly based on improvement on the side of working conditions and not necessarily on the wages. Hence the contradictions on the effects of the regulation of the domestic workers. It is therefore safe to conclude that to a greater extent this regulation has reduced the status of the domestic workers to beggars than choosers than before.

\section{Improving the Effectiveness of the Basic Conditions of Employment Act for Domestic Workers}

Domestic employers play a significant role in assisting the government to achieve a significant level of improved employment in the country of employment. Statistics indicated in 2003 that domestic work contributed for between 5 and $8.7 \%$ of the total workforce in South Africa (du Toit, 2010; Sjoberg, 2011: 20). It is however notable that the figure as reported in 2003 declined when the act was implemented and later increased between 2007 and 2010. Both the decline and the decrease of employment in the sector is of significant in the sense that it shows that domestic employment 
continues to be viewed by employees in the sector as a quick solution to employment problem in the country. The approach of the South African government on this affair through the enactment of the Basic Conditions of Employment Act (Domestic workers) have but been practiced like a punitive measure to the employers in this category as if all domestic employers are exploitative and abusive to their employees( Stiell \& England, 1997). A widespread of abuse of domestic workers has however been reported (Albin \& Mantouvalou, 2011) even though such reports named the immigrants as victims of such exploitation and abuse. But that cannot be used to generalize the conditions of domestic workers in countries of employment to the extent that even those treating their employees with dignity can be included in the category of abusers.

The current minimum rate as set from 01 December 2012 to December 2013 is worked at R 1746.00 per month (Bernard, 2012:3) for domestic employees in urban areas, while for those in rural areas would be lesser in comparison. This does not mean that there are no employers who are not paying their employees above the minimum wage requirements as set by the state. The recent strike in the Agricultural sector in the Western Cape resulted in the minimum wage in the sector being raised to R 2, 274.82 per month (Paton, 2013:1-2), which is a threat to large scale job losses and bankruptcy of farmers businesses if no due consideration is taken on their increased expenditure. Studies conducted in the country (Stanwix, 2013:2) showed that between 2003 and 2007 the agricultural sector in the Western Cape have been paying employees' wages that were close or above minimum acceptable wage by the legislation as compared to any other province in South Africa. While in South Africa it is argued that there is no a single minimum wage for all sectors, that even within the sector there are variances in terms of occupational categories and job types what is clear is that the minimum wage legislation is implemented in a manner that disadvantage the beneficiaries than to assist them. $\mathrm{A}$ variety of literature on the subject revealed that the minimum wage legislation have indeed improve wages and salaries of employees in the sector, but at the same responsible for job decline although not yet scientifically verified through empirical studies. Based on this; this article suggests the following measures to improve the efficiency of the minimum wage legislation; Incentivizing employers, regulate in terms of income and creating state supported day care centres.

\subsection{Incentivizing employers}

Domestic employers are by all means playing an important role in reducing unemployment rate in the country. Literature on this subject revealed that recent global statistics shows that at least 52.6 million of men and women above the age of 15 were employed in the domestic sector and that domestic employment contributes to 3.6 of global wage employment (D'Souza, 2010). In both developing and developed countries domestic work is believed to absorb a significant number of employees (International Labour Organisation, 2012: 1) thus making a significant impact on unemployment reduction. Despite the significant role played by these domestic employers in employment, little is reported in positive light of employers' contribution in the sector. The system paints them all with one brush as abusers, exploiters and harassers of employees in their service. If this sector is formalized like all other sectors of the economy, then employers in the category should receive similar treatment with other employer category such as receiving tax rebates. These employers use more of their already taxed income to assist the government in achieving good economic growth rate through employment. Coming up with a system of supporting employers in this category can help in improving the living and the status of employees in the sector.

\subsection{Regulate minimum wages according to income}

Domestic workers which mostly are women in South Africa and world over (Tonkin, 2010; African National Congress, 2012: 2) are employed by employers of various occupational categories and social status in the sense that not all of such employers can afford to comply even if they so much wish to. Some employers themselves in these categories are not afforded to by their own employers. Like all other business organisations that have different strengths, weaknesses and opportunities, individual employers in these category experiences similar challenges in meeting minimum wage legislation. A practical example could be that a youthful unmarried mining operator earning a minimum of $\mathrm{R} 3500$ basic salary requires the services of a domestic worker to look after her 3 year old baby and her rented flat at R800 per month excluding services would find it difficult to afford the legislated minimum wage. The minimum wage could only be afforded by particular salary levels in the employment category. As argued in this article, that there are specific unreal situation in regard to the implementability of the act because a domestic worker paid a minimum wage by his or her employer may also be obliged to engage the services of a domestic worker and this will in all probability makes it difficult for the primary domestic worker to comply to the secondary employer needs. As Stanwix (2013:4) argued the effectiveness of this legislation remain un-researched in most of the cases hence leading to more non-compliance from the employers. While 
further research on the effectiveness of this legislation is necessary, an open answer is that legislators in this regard are to consider the significant role played by various employer categories in this sector and accept that not all of them can afford to comply with the minimum wage legislation. It is unfair that a one size fits all approach be adopted to cover even for legislators who themselves earns millions per annum to have a minimum wage set for them at the level of the minimum to be paid by another employer in another sector earning an average of R60 000 per annum. It would really make sense if the state considers setting the minimum wages on the basis of the income earned by the employers.

\subsection{State aided care centers}

Domestic work is a necessity especially in young families and employable households. Of utmost significance is that such families need domestic employees mostly for elderly and child care support (Karol, 2006 \& Matjeke et al, 2012). While physical presence of a domestic worker is important for security of employer's properties, it is also important to note that domestic workers can provide other services that cannot be provided by formal care centers such as the ability to improve the speech development of the child taken care of. Of course most domestic employers will prefer employing a child minder who speaks the local language. This however differs in racial terms in South Africa where domestic employment is an occupation of black South African women (African National Congress, 1980:1-2). Even in that instance white South African domestic employers prefers a domestic employee who is competent in their language. Since the minimum wage legislation threatens the sustainability of this occupational category in terms of job creation (Matjeke et al, 2012) it is important that the state can take over the responsibility of this formalized employment category by creating in each settlement state aided care centers where employment of the domestics can be created with easy.

\section{Conclusion}

This article argued that the minimum wage legislation set for domestic workers is likely to result in job losses than assisting in the improvement of the working conditions of the domestic workers in South Africa. The article therefore conclude that while the improvement of the working conditions of the domestic workers is important- the state should consciously ensure that they take decisions that does not limit the benefits of the policy to the intended beneficiaries. Taking into consideration the negative effects associated with the implementation of the policy, the article recommended that the state should consider incentivizing domestic employers through created state support fund, regulating wages in terms of income and provision of state funded care centres to sustain the employment of domestic workers in all areas of settlement.

\section{References}

Albin, E. \& Mantouvalou, V. (2011). The ILO convention on domestic workers: From the shadows to the light. UCL Labour Rights Institute On-line working papers-LRI WP1/2011.

Altman, M. (2006). Wage determination in South Africa: What do we know? Transformation. (60):58-88

African National Congress, (1980). Effects of Apartheid on the Status of women in South Africa. Available at http://www.anc.org.za/show.php?id=4668\&t=ES. Accessed on 12/03/2013

Babin, A. (2013). Domestic workers. Available at http://www.ilo.org/safework_booksshelf/english?conte

Nt\&nd $=857171216$, accessed on 01/03/2013

Blaauw, P.F \& L.J Bothma (2010). The impact of minimum wages for domestic workers in Bloemfontein, South Africa. South African Journal of Human Resources. Vol 8(1): 1-7

Bernard, R. (2012). Minimum wage increases for domestic workers. Available at http://www.capelabour.co.za/blog/minimum-wageincrease-for-domestic-workers.html accesed on 01/03/2013

Bothma, L \& Campher, C. (2003). Minimum wage for domestic workers: a comprehensive analysis. Acta Academia 35(1)190-250.

Burgher, R \& Fintel, D. (2009). Determining the causes of the rising South African Unemployment rate: An age. Period and Generational Analysis. Cape Town: Stellenbosch University.

Curry, E. (2011). South Africa: Convention to secure decent work for domestic workers. Inter press service News Agency. Available at htpp://www.ipsnews.net/2011/03south-africa-convention-to-secure-decent-work-for-dome. accessed on12/03/2013

D'Souza, A. (2010). Moving towards decent work for domestic workers: An overview of the ILO's work. International Labour Office: Bureau for gender equality: working paper no.2. Geneva: International labour Organisation

Dilata, X. \& Ngoepe, KR. (2010). The study of African domestic workers and their African employers in the townships of Soweto. Domestic workers Research Project. Cape Town: University of Cape Town.

Department of Labour (2010). Job opportunities and unemployment in the South African labour market. Pretoria: Government Printer

Du Toit, D. (2010). Extending the frontiers of employment regulation: The case of domestic employment in South Africa. Law, 
Development and Democracy. Vol (14): 1-22

Employment Conditions Commission,( n.d). Recommendations of the employment conditions commission on the investigation into the domestic worker sector. Pretoria: Government Printer

Freeman, A. Roberts, K. Tretjak, K. \&Wiener, C. (2003). Assesing the rights of migrant domestic workers in the United States, seeking alternatives. United States of America: International Human Rights Clinic.

Gobind, J. du Plessis, G \& Ukpere, W. (2012). Minimum wage and domestic workers' right to basic conditions: Are employers complying? African Journal of Business Management 6(47) 11683-11691

Hertz, T. (2005). The effect of minimum wages on the employment and earnings of South Africa's domestic service workers. Development Policy Research Unit Working Paper, 05/99. Available at http://www.commerce.uct.ac.za/dpru/ accessed on 03/03/2013

International Labour Organisation, 2006

Karol, R. (2006). Elder care: A responsibility that requires a collaborative effort. Worldatwork journal 15(3)

Matjeke,A. Viljoen, J.M. \& Blaauw P.F. (2012). The effect of labour market regulation on domestic workers in Orchards and Soshanguve, Pretoria. SA Journal of Human Resource Management 10(1) 1-11.

Paton, C. (2013). Minister reveals new minimum wage for farm workers. Business Day Live.

Stanwix, B. (2013). Minimum wage and compliance in South African culture. Cape Town: University of Cape Town.

Sjoberg, E. (2011). Enforcement of laws regulating domestic work: A case study of South Africa. Master thesis: Lund University.

Stiell, B. \& England, K. (1997). Domestic Distinctions: constructing difference among paid domestic workers in Toronto. Gender, Place and Culture 4(3)339-359.

Pheko, L. (2012) "The help" Disregards agency of black women: South African Civil Society Information Service.

Statistics South Africa. (2009). Pretoria: Government printers.

The International labour Organisation. (2012). Making decent work a reality for domestic workers worldwide. International Labour Organisation Publications: Geneva

Tonkin, A. (2010). The plight of domestic workers: The elusiveness of access to adequate housing. Law, democracy and development 14(1) 354-368. 
